\title{
Plasma Cyclic Nucleotide Determination in the Investigation of Hypocalcemia
}

\author{
ERIC MALLET, JEAN-PIERRE BASUYAU, PHILIPPE BRUNELLE, AND CLAUDE H. DE MENIBUS \\ Unite d'explorations fonctionnelle, Pavillon de Pédiatrie Hôpital Charles Nicolle, Centre Hospitalo-Universitaire de \\ Rouen (E.M., C.H.D.M.) and Laboratoire de Biochimie, Centre HenriBecquerel, 76038 Rouen Cédex (France) \\ (J.P.B., P.B.)
}

\begin{abstract}
Summary
Changes in plasma adenosine $3^{\prime} 5^{\prime}$ (cAMP) and guanosine (cGMP) monophosphate, measured by specific radioimmunoassay, after $150 \mathrm{USP} / \mathrm{M2}$ of bovine parathyroid hormone (bPTH) iv administered were studied in children with pseudohypoparathyroidism, with idiopathic hypoparathyroidism, and in normal controls. Basal concentrations of plasma cAMP (17 nmole/1 $\pm 1,6$ SEM) and cGMP $(8,7$ nmole/1 $\pm 1,3$ SEM) were the same in all studied children. Plasma cAMP in normal and idiopathic hypoparathyroid children significantly $(30$-fold, $P<0.001)$ and con-
\end{abstract}

stantly rose with a peak value $(537 \mathrm{nmole} / 1 \pm 210 \mathrm{SEM})$ observed 5-10 min after bPTH injection. By contrast, no significant change in plasma cAMP occurred in children with pseudohypoparathyroidism. The data confirmed further the unability of pseudohypoparathyroid children to increase cAMP after exogenous PTH, while the cGMP response did not appear to be significantly modified. It is suggested that an injection of $150 \mathrm{USP} / \mathrm{m} 2 \mathrm{bPTH}$ with plasma samples for cAMP assay taken before and $10 \mathrm{~min}$ after hormone administration represents a simplified assessment of Ellsworth-Howard's test. 
The syndrome of pseudohypoparathyroidism clinically characterized by short tature, mental retardation, rounded face and short stubby hands, and an apparent target organ resjstance to parathyroid hormone, was first described by ALBRIGH T CHASE subsequently demonstrated that patients with pseudohypoparathyroidism had defective urinary cAMP excretion after receiving bovine parathyroid hormone (BPTH) ${ }^{2}$ The role of cAMP as an intracellu the physiological role of cGMP is still unclear.

These two nucleotides seem to have antagonistic effects in a number of biological systems. PTH has been shown to increase urinary cGMP and cAMP excretion, but few studies bave considere the phênomenon for cyclic nucleotide plasma exit from specific tissues $5, B$.

We studied the effect of B.PTH Injection on plasma cAMP and cGMP in three groups of children : 1) pseudohypoparathyroid patients, 2) hypoparathyroid patients and 3) normallcontrols, in an effort to observe differences among them and to make practical recommendations for the investigation of hypocalcemia. Preliminary results have been previously reported 6 .

\section{PATIENTS AND METHODS}

Six helthy, seven hypoparathyrold and two pseudohypoparathyroid children were dtudied (table 1) informed parental consent was obtained. Plasma cAMP determination was performed by radiocompetition using a binding protein purified from bovine muscle? dadspáanghcGMP by radioimmunoassay (AMERSHAM) kits. Plasma IPTH détermination was performed with a radioimmunoassay previously described using BW 211/32 antiserum (WELCOME) and the standard B.PT supplied by the Medical research Council (Hampgtead f ENGLAND). 150 USP units/m2 of body surface aera of $B P T H^{2}$ were administered intravenously. 1 ml EDTAs blood samples were drown immediately before, $5,10,20,30,40,60$ and 90 minutes after BPTH injection. statistical analysis was performed with the MANN-WHITHEY test.

\section{RESULTS}

Basal concentrations of plasma cAMP ( $17 \mathrm{nmol} / 1 \pm 1,6$ SEM) and $\operatorname{cGMP}(8,7 \mathrm{n}$ mol/1 $+1,3$ SEM) Mere similar in all three groups. After BPTH injection, plasma cGMP increased two to three fold, th peak occuring 10 to 30 minutes after injection without any signifi cant difference among the thred groups. In contrast in normal and idippathic hypoparathyroìd children, plasan cAMp rèoe significantly ( 30 fold, $p<0,001$ ) and constantly, with a peak value at 5 to 10 minutes after BPTH infection (controls: $537 \mathrm{nmol} / 1+210$ SEM and hypoparathyroid children : $490 \mathrm{n}$ mol/1 \pm 150 SEM). Conversely, children with peeudohypoparathyroidism showed no significant chan$\mathrm{ge}$ in plasma cAMP (case) : $40 \mathrm{nmol} / 1$, case $2: 36 \mathrm{nmol} / 1$ at 60 minutes) ( $f$ ig. I).

\section{DIBCUSSION AND CONCLUSIONS}

These results further confirm the unability of pseudohypoparathyroid children to increase cAMP following administration of exogenous PTH, while retaining an apparently unmodified cGMP response. The validity of this method as a PTH renal responsivness test is relative to the fact tahat the marked effect ofn PTH upon cAMp is chiefly due to the increment from the kidney. Indeed KAMINSKY did not observe any modification of plasma cAMP in anephric patients

As suggested by TOMLINSON ${ }^{\theta}$, our observations indicate that cAMP assays with 1 ml blood samples taken before and 10 minutes after BPTH injection are a simple substitute for the classical a ter BPTH injection a precluding the necessity of collecting

urine samples.

ss Vacutainer (Beckton-Dickinson)

\section{REFERENCES}

1 - AlBRight F, BURNETT CH, SMITH PH, PARSON W : Pseudohypoparathyroldism : an example of "seabright-bantam syndrome" : repor

2 of of three cases, Endocrinology 30 : 922 , (1942). defective excretion of 3 ' 5 , AMP in response to parathyroid hormomone, J Clin Invest 48-1, 832, (1969)

3 - ELLSWORTH R, HOWARD JE : Studies on the physiology of the parathyroid glands. Some responses of normal human kidneys and blood to IV parathyroíd extract, Bull, John's Hopkins Hosp 55: $296(1934)$.

4 - GOLDBERG ND, HADDOX MX, NICOL SE, GLASS DB, SANFORD CH, KUEHL FA Jr, and ESTENSEN R : Biodogic regulation through opposing influences of cyclic GMP and cyclic AMP : the Yin Yang Hypothesis Advances in cyclic Nucleotides Research vol 5, Raven Bress. New-York 1975.

5 - KAMINSKY NL, BROADUS AE, HARDMAW JG. JONES PJ Jr, BALL JH, SUTKERLAND EW, LIDDLE GW : Effects of parathyroid hormone on Invest $49: 2,387,(1970)$.

6 - MALLET E, BASUYAU JP, BRUNELLE PH, DE MENIBUS CH : Plasma nucleotides cAMP and cGMP responsivness to parathyroild hormone in pseudohypoparathyroídism Ped Res $11: 1022$ (bstract), (1977).

Copyright $\odot 1979$ International Pediatric Research Foundation, Inc. 0031-3998/79/1305-0647\$02.00/0
7 - Mallet E, BRUNelle PH : Technique de dosage radioimmnologique de 1 a parathormone humaine : utilisation d'un antisérum disponible et

8 - TOMLINSON S, HENDY GN, O'RIORDAN JLH : A simplified assessment of response to parathyroid hormone in hypoparathyroid patients Lancet 1: 62 (1976)

9 - WEHMANN RE, BLONDE L, STEINER AL : Source of cyclic nucleotide in plasma $\mathrm{J}$ Clin Invest $53: 173,(1974)$

10- WILLIAMS RH, BARISH J, ENSINK JW : Hormone effects upon cyclic aucleotide excretion in man, Proc Soc Exp Biol Med 139:447

11- Requests for reprints should be adressed to E. MALLET, Md Unité d'explorations fonctionnelles - Pavillon de Pédiatrie ôpital Charles Nicolle - Centre Hospitalo-Universitaire de ROUEN.

12- Received for pkblication may 22, 1978

- Accepted for publication October 9 , 1978 , Hopital saint-Vincen The Authors thank to his study.

Abbreviations used :

IPTH immunoreactive parathyroid hormone BPTH bovine parathyroid hormone

CAMP adenosine $3^{\prime} 5^{\prime}$ monophosphate

cGMP guanosine 3'5' monophosphate

EDTA ethylène diamine tetraacetate

\begin{tabular}{|c|c|c|c}
\hline & $\begin{array}{c}\text { NORMAL } \\
\text { CONTROLS }\end{array}$ & $\begin{array}{c}\text { IDIOPATHIC } \\
\text { HYPOPARATHYROIDISM }\end{array}$ & $\begin{array}{c}\text { PSEUDO- } \\
\text { HYPOPARATHYROIDISM }\end{array}$ \\
\hline N & 6 & 7 & 2 \\
\hline Plasma Ca mg/dl range & $9.2-10.2$ & $4.8-6.1$ & 5.3 and 8.6 \\
"P mg/dl " " IPTH ng/ml & $4.1-5.5$ & $6.5-10$ \\
& $0.8-1.4$ & undetectable -0.9 & $2.3 " 3.9$ \\
& & & 3.2 \\
\hline
\end{tabular}

Table I Children studied

IPTH sormal values $1.2 \pm 0.3 \mathrm{ng} / \mathrm{ng}$ (mean $\pm 1 \mathrm{SD}$ )
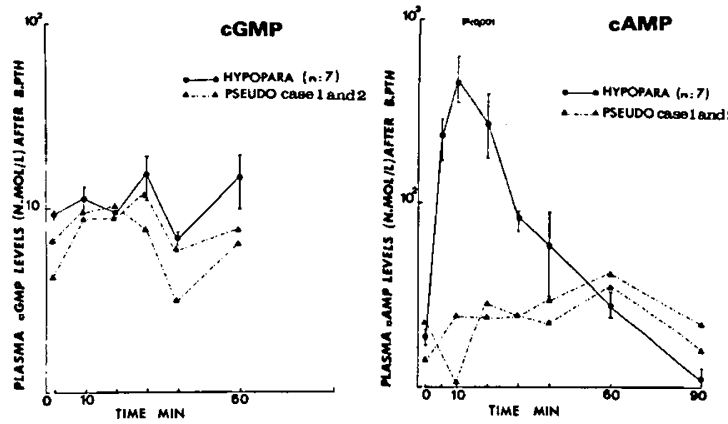

Figure 1: P1asma CAMP and CGMP responsivness to Parathyroid hormone in children with hypoparathyroïdism and pseudo hypoparathyroidism. 